\title{
Differences in growth rates among cohorts of Encrasicholina punctifer and Engraulis japonicus larvae in the coastal waters off Tanshui River Estuary, Taiwan, as indicated by otolith microstructure analysis
}

\author{
Yu-Tzu Wang and Wann-Nian Tzeng \\ Department of Zoology, College of Science, National Taiwan University, Taipei, \\ Taiwan 10617, R.O.C.
}

(Received 9 May 1998, Accepted 14 January 1999)

\begin{abstract}
The hatching dates of Encrasicholina punctifer and Engraulis japonicus larvae collected in the coastal waters off Tanshui River Estuary during the fishing seasons of 1992 and 1993 indicated that these two anchovies had protracted spawning seasons, which resulted in multiple recruitment cohorts. Encrasicholina punctifer larvae recruited to the estuary from October to March, while the majority of E. japonicus larvae came in March-May and to a lesser extent in October and November. The E. punctifer larvae on arrival to the estuary were $17.4-35.6 \mathrm{~mm}$ in length, 16-89 days old and had growth rates of 0.4-1.0 $\mathrm{mm}^{-1 a y}{ }^{-1}, E$. japonicus larvae were $12 \cdot 1-32.7 \mathrm{~mm}$ in length, 19-62 days old and had growth rates of $0 \cdot 7-0.9 \mathrm{~mm}^{-1 a y}{ }^{-1}$. Growth rates were significantly different among cohorts and positively correlated to water temperature.

(C) 1999 The Fisheries Society of the British Isles
\end{abstract}

Key words: Encrasicholina punctifer; Engraulis japonicus; larvae; otolith; growth rate; water temperature; Taiwan.

\section{INTRODUCTION}

Early life history may be a critical period in determining the year-class strength of fish stocks (Hjort, 1914; Cushing, 1975; Smith, 1985). Growth in the early life stages will influence survival and subsequent recruitment. Small changes in growth rates may give rise to a dramatic effect on recruitment by extending stage durations over which high mortality may operate (Houde, 1987).

In the past, growth rates of larval fishes were determined from lengthfrequency distributions using a modal progression method. This method can provide only mean growth estimates for larval populations and may be biased by age- and cohort-specific changes in growth rates (Crecco et al., 1983). These estimates are averaged over months and years, but the critical life history events can occur on short temporal scales of hours or days (Fortier \& Leggett, 1985). Many pelagic fishes in the tropical and sub-tropical regions, have protracted spawning seasons which lead to multiple recruitment cohorts. Because of the difficulties in connecting length modes in polymodal distributions, this may complicate growth estimates further (Lough et al., 1982). Accordingly, the growth rate of fish in early life history cannot be determined accurately by length-frequency distribution analysis.

Tel.: +886 2 23639570; fax: +886 2 23636837; email: wnt@ccms.ntu.edu.tw 
Since Pannella (1971) discovered daily growth increments in otoliths of fishes, they have become a powerful tool in ageing the larvae of fishes. Daily increments in at least 50 families and 300 species have been recognized (Secor et al., 1992). Counts of daily growth increments allow a direct measure of length-at-age. This information can be used to calculate growth rates (Struhsaker \& Uchiyama, 1976; Methot \& Kramer, 1979; Secor \& Dean, 1989) and to estimate temporal distributions of birthdates (Townsend \& Graham, 1981; Methot, 1983). Then, the variability in growth rates can be compared among spatial (Methot, 1983) and temporal scales (Jones, 1985; Leak \& Houde, 1987; Moksness \& Fossum, 1991, 1992). In addition, through the backcalculation of distribution of birthdates, the cohorts of the fishes spawned in a protracted spawning season can be discriminated, and the variability of growth rates among cohorts can be elucidated (Crecco \& Savoy, 1985; Al-Hossaini et al., 1989; Thorrold \& Williams, 1989; Rutherford \& Houde, 1995).

Engraulis japonicus Schlegel and Encrasicholina punctifer Fowler larvae were the most dominant group in larval fish assemblages in the coastal waters off Tanshui River Estuary. They showed a distinct temporal succession when they recruited into the estuary (Tzeng \& Wang, 1992; Wang \& Tzeng, 1997a). This paper aims to determine the age of the larvae by examining daily growth increments in otoliths and to elucidate if growth rates of the larvae were different among cohorts.

\section{MATERIALS AND METHODS}

\section{SAMPLING DESIGN}

Encrasicholina punctifer and Engraulis japonicus larvae drifting with tidal currents in the Tanshui River Estuary were harvested daily by a commercial net from May 1992 through November 1993. The structure and dimension of the net were the same as in a previous study (Wang \& Tzeng, 1997a). Approximately $10 \mathrm{~g}$ wet-weight larvae were selected randomly from the daily catch and preserved in $95 \%$ alcohol.

A total of 26343 larvae from 109 samples were examined. Encrasicholina punctifer and E. japonicus were the most dominant species in the 48 families and 124 species identified (Wang \& Tzeng, 1997a, b). Daily catch per unit of effort (cpue) of these two species was calculated to understand their temporal recruitment dynamics. For age and growth assessment, the samples around the peak catch in each month were collected (Fig. 1). Four samples on 18, 20, 21, and 23 October, and three samples on 25, 26, and 30 November, and one sample on 2 December and on 16 February were collected, respectively, for E. punctifer larvae. Four samples on 18, 20, 21, and 23 October, and two samples on 25, 27 March, two samples on 20,26 April, and two samples on 25, 26 May were collected, respectively, for E. japonicus larvae (Table I).

\section{OTOLITH PREPARATION AND MEASUREMENT}

Standard lengths $\left(L_{\mathrm{S}}\right)$ of the fish were measured to the nearest to $0 \cdot 1 \mathrm{~mm}$ (Table I). Sagittae, the largest pair of otoliths of the fish, were removed with a sharpened needle, dried in air, and mounted on slide with permount for microscopic examination.

Daily growth increments (DGI) in the sagittal otoliths were examined with a transmitted-light microscope; maximum radius from nucleus to the posterior margin of the otolith was measured to the nearest to $0 \cdot 1 \mu \mathrm{m}$ with the aid of an image process system (LV2) (Table I). The mean widths of every three increments in an otolith along the maximum radius were calculated to reconstruct the growth history of an individual on the assumption that growth of body was proportional to otolith growth. 


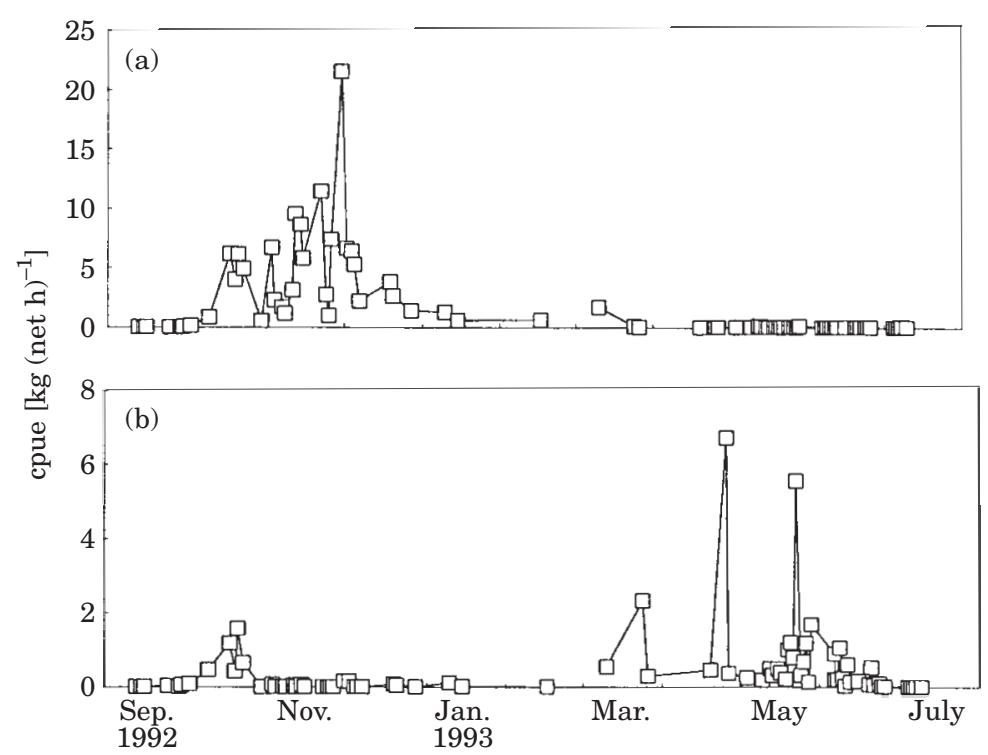

FIG. 1. Daily changes in catch per unit effort (cpue) of Encrasicholina punctifer (a) and Engraulis japonicus (b) larvae in the coastal waters off Tanshui River Estuary, September 1992-July 1993.

\section{DATA ANALYSIS}

The daily age of E. japonicus larvae was calculated from the counts of DGI plus 4 days of yolk-sac period (Tsuji \& Aoyama, 1984), while that of E. punctifer was not adjusted because it was a tropical species whose first otolith daily growth increment was assumed to be deposited at hatching (Thorrold, 1989). Hatching date of the larvae was backcalculated from the daily age and date of capture.

Somatic growth rate $(G)$ of the larvae was calculated from the length and the daily age at estuarine arrival as follows:

$$
G\left(\mathrm{~mm} \mathrm{day}^{-1}\right)=L_{\mathrm{S}} \times(\text { age in days })^{-1}
$$

The differences in mean otolith length, width, and maximum radius of otolith and DGI counts between the left and right otoliths were determined by paired $t$-test. The differences in mean standard length, daily age and somatic growth rate among dates of capture were determined by one-way analysis of variance (ANOVA). The differences in 3-day mean increment widths among months (cohorts) and over time were analysed by repeated-measures ANOVA (Winer, 1971). The relationship between growth rate and water temperature was fitted by a linear regression. The water temperature used in the relationship was an average which was backcalculated from when the larva was caught in the estuary to its estimated hatching date. The regression of fish length on age among months was compared by analysis of covariance (ANCOVA) (Steel \& Torrie, 1980).

\section{RESULTS}

\section{RECRUITMENT DYNAMICS}

The timing of recruitment to the estuary was different between Encrasicholina punctifer and Engraulis japonicus. Encrasicholina punctifer larvae recruited to the estuary, mainly from October to March, and E. japonicus from March to May with a minor peak in October (Fig. 1). 
TABle I. Sampling date, sample size, standard length, and maximum radius of sagittal otolith of Encrasicholina punctifer and Engraulis japonicus larvae used in this study

\begin{tabular}{|c|c|c|c|c|c|c|}
\hline \multirow{2}{*}{ Species } & \multirow{2}{*}{$\begin{array}{l}\text { Sampling } \\
\text { date }\end{array}$} & \multirow{2}{*}{$\begin{array}{c}\text { Sample } \\
\text { size }\end{array}$} & \multicolumn{2}{|c|}{$L_{\mathrm{S}}(\mathrm{mm})$} & \multicolumn{2}{|c|}{ Maximum radius $(\mu \mathrm{m})$} \\
\hline & & & Range & Mean \pm S.D. & Range & Mean \pm S.D. \\
\hline \multirow{10}{*}{ E. punctifer } & 18 Oct. & 30 & $17 \cdot 4-29 \cdot 3$ & $24 \cdot 7 \pm 2 \cdot 8$ & $126 \cdot 69-335 \cdot 12$ & $231 \cdot 87 \pm 51 \cdot 59$ \\
\hline & 20 Oct. & 30 & $17 \cdot 6-29 \cdot 5$ & $25 \cdot 2 \pm 3 \cdot 3$ & $145 \cdot 20-369 \cdot 90$ & $254 \cdot 29 \pm 64 \cdot 86$ \\
\hline & 21 Oct. & 30 & $20 \cdot 9-33 \cdot 5$ & $25 \cdot 4 \pm 3 \cdot 3$ & $177 \cdot 38-415 \cdot 22$ & $254 \cdot 86 \pm 67 \cdot 75$ \\
\hline & 23 Oct. & 30 & $18 \cdot 2-32 \cdot 5$ & $25 \cdot 3 \pm 3 \cdot 1$ & $137 \cdot 34-410 \cdot 68$ & $239 \cdot 10 \pm 60 \cdot 89$ \\
\hline & 25 Nov. & 30 & $18 \cdot 5-24 \cdot 3$ & $20 \cdot 5 \pm 1 \cdot 6$ & $115 \cdot 89-213 \cdot 73$ & $148 \cdot 06 \pm 21 \cdot 92$ \\
\hline & 26 Nov. & 30 & $18 \cdot 1-26 \cdot 9$ & $20 \cdot 9 \pm 1 \cdot 9$ & $119 \cdot 53-261 \cdot 02$ & $166 \cdot 03 \pm 31 \cdot 08$ \\
\hline & 30 Nov. & 30 & $18 \cdot 4-35 \cdot 6$ & $25 \cdot 1 \pm 4 \cdot 8$ & $130 \cdot 95-433 \cdot 68$ & $232 \cdot 13 \pm 88 \cdot 52$ \\
\hline & 2 Dec. & 30 & $21 \cdot 1-35 \cdot 0$ & $26 \cdot 9 \pm 3 \cdot 0$ & $175 \cdot 03-426 \cdot 72$ & $266 \cdot 65 \pm 58 \cdot 8$ \\
\hline & $16 \mathrm{Feb}$. & 21 & $17 \cdot 8-30 \cdot 0$ & $24 \cdot 0 \pm 3 \cdot 0$ & $83 \cdot 22-311 \cdot 49$ & $186 \cdot 79 \pm 60 \cdot 62$ \\
\hline & Overall & 261 & $17 \cdot 4-35 \cdot 6$ & $24 \cdot 2 \pm 3 \cdot 7$ & $83 \cdot 22-433 \cdot 68$ & $220 \cdot 42 \pm 71 \cdot 93$ \\
\hline \multirow[t]{11}{*}{ E. japonicus } & 18 Oct. & 10 & $21 \cdot 7-28 \cdot 7$ & $25 \cdot 5 \pm 1 \cdot 8$ & $181 \cdot 88-250 \cdot 57$ & $220 \cdot 26 \pm 22 \cdot 81$ \\
\hline & 20 Oct. & 4 & $25 \cdot 7-29 \cdot 3$ & $28 \cdot 1 \pm 1 \cdot 4$ & $226 \cdot 97-347 \cdot 79$ & $281 \cdot 94 \pm 45 \cdot 30$ \\
\hline & 21 Oct. & 14 & $24 \cdot 0-31 \cdot 5$ & $28 \cdot 1 \pm 2 \cdot 2$ & $219 \cdot 20-380 \cdot 16$ & $292 \cdot 62 \pm 53 \cdot 74$ \\
\hline & 23 Oct. & 6 & $24 \cdot 3-32 \cdot 7$ & $28 \cdot 8 \pm 2 \cdot 9$ & $214 \cdot 63-457 \cdot 90$ & $299 \cdot 89 \pm 87 \cdot 02$ \\
\hline & 25 Mar. & 30 & $12 \cdot 6-27 \cdot 8$ & $19 \cdot 2 \pm 4 \cdot 4$ & $64 \cdot 63-234 \cdot 28$ & $120 \cdot 79 \pm 43 \cdot 71$ \\
\hline & 27 Mar. & 29 & $12 \cdot 1-25 \cdot 8$ & $20 \cdot 4 \pm 3 \cdot 9$ & $58 \cdot 54-207 \cdot 40$ & $132.82 \pm 36.79$ \\
\hline & 20 Apr. & 30 & $16 \cdot 9-23 \cdot 3$ & $20 \cdot 1 \pm 1 \cdot 8$ & $95 \cdot 46-175 \cdot 84$ & $138 \cdot 25 \pm 19 \cdot 82$ \\
\hline & 26 Apr. & 30 & $15 \cdot 6-28 \cdot 7$ & $21 \cdot 6 \pm 3 \cdot 3$ & $78 \cdot 07-257 \cdot 32$ & $143 \cdot 76 \pm 41 \cdot 64$ \\
\hline & 25 May & 21 & $15 \cdot 0-26 \cdot 7$ & $20 \cdot 0 \pm 3 \cdot 2$ & $101 \cdot 22-220 \cdot 79$ & $147 \cdot 11 \pm 37 \cdot 03$ \\
\hline & 26 May & 30 & $15 \cdot 8-24 \cdot 9$ & $20 \cdot 5 \pm 2 \cdot 5$ & $118 \cdot 71-232 \cdot 95$ & $159 \cdot 37 \pm 28 \cdot 24$ \\
\hline & Overall & 205 & $12 \cdot 1-32 \cdot 7$ & $21 \cdot 5 \pm 4 \cdot 2$ & $58 \cdot 54-457 \cdot 90$ & $161 \cdot 92 \pm 65 \cdot 09$ \\
\hline
\end{tabular}

There were five peak recruitment cohorts for E. punctifer, occurring on 18 October, and 3, 12, 22, and 30 November. The highest peak was on 30 November. Each peak recruitment duration lasted 2-4 days. The recruitment interval was $c .10$ days.

There were four peak recruitment cohorts for E. japonicus, on 21 October, 25 March, 25, 26 April, and 23 May. The highest peak was on 26 April. Each peak recruitment duration lasted 3-4 days. The recruitment interval was $c .1$ month.

\section{DAILY GROWTH INCREMENTS IN OTOLITHS}

The shape of sagittal otoliths of both E. punctifer and E. japonicus larvae is round in the early stage and gradually extends anteriorly with growth. DGI in otoliths of the larvae were clearly discernible with a transmitted-light microscope and no sub-daily increments were found; increment width of the otolith of E. japonicus was wider than that of E. punctifer (Fig. 2).

There were no significant differences in maximum radius $(n=30$, E. punctifer, $t=-1.28$ and E. japonicus: $t=1.23)$ or in the number of DGI $(t=0.00$ and -0.54 ) between left and right sagittae. Accordingly, either right or left sagittae could be used for age and growth assessment.

\section{HATCHING DATES}

Hatching dates of E. punctifer and E. japonicus larvae were separated distinctly among sampling months (Fig. 3). This indicated that they belonged to different 

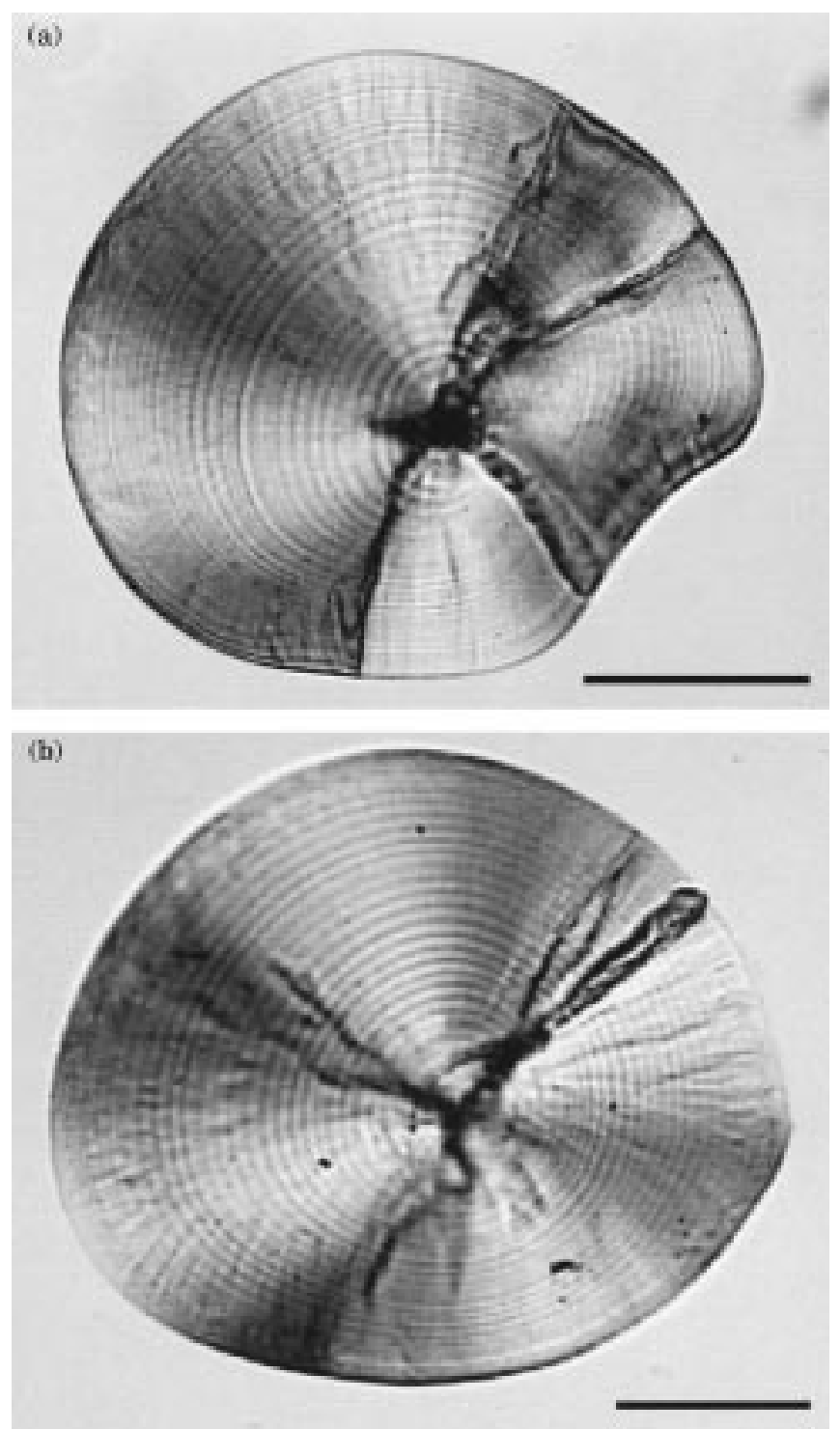

FIG. 2. Daily growth increments in otoliths of Encrasicholina punctifer larva collected on 26 November 1992 (25 days old, $19 \cdot 5 \mathrm{~mm} L_{\mathrm{S}}$ ) (a) and Engraulis japonicus larva collected on 27 March 1993 (26 days old, $25 \cdot 2 \mathrm{~mm} L_{\mathrm{S}}$ ) (b) from the coastal waters off Tanshui River Estuary. Scale bar $=100 \mu \mathrm{m}$.

cohorts. Encrasicholina punctifer larvae collected on 18, 20, 21 and 23 October were hatched during the period from 14 September to 7 October (peak on 26 September), those collected on 25, 26, and 30 November and 2 December were hatched from 8 October to 12 November (1 November), and those collected on 16 February were hatched from 19 November to 15 January (8 December). The durations from hatching dates to the time when the larvae were collected in the estuary in October, November and February were c. 24, 37, and 58 days, respectively. This indicated that the later-hatched larvae delayed recruitment to the estuary. 


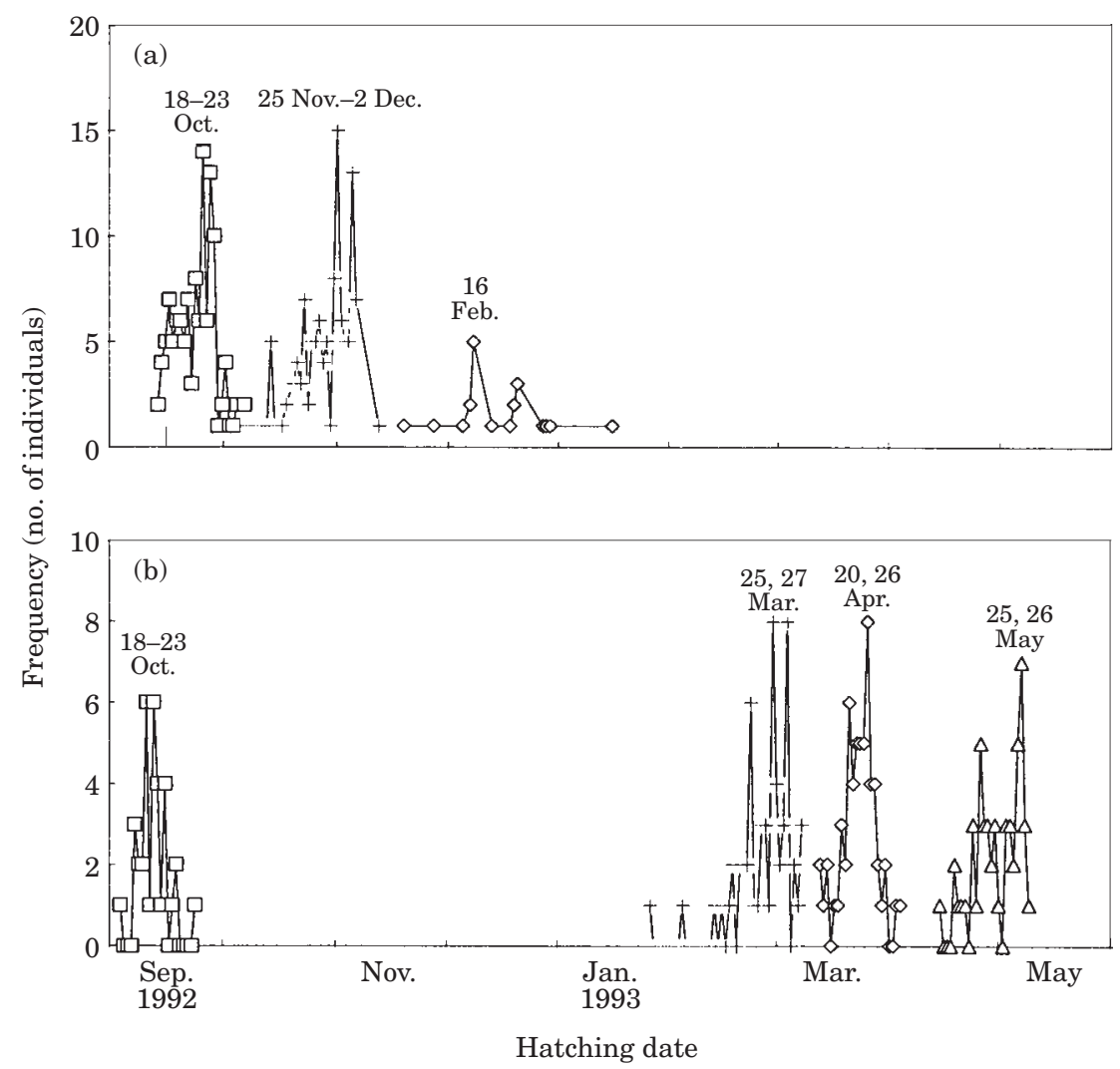

FIG. 3. Distributions of estimated hatching dates of Encrasicholina punctifer (a) and Engraulis japonicus (b) larvae collected in the coastal waters off Tanshui River Estuary. Sampling dates indicated in the diagram.

Engraulis japonicus larvae collected in the estuary on 18, 20, 21 and 23 October were hatched during 4-24 September (peaked on 13 September), those collected on 25 and 27 March were hatched during 26 January-9 March (peak, 1 March), those collected on 20 and 26 April were hatched during 14 March-5 April (peak, 27 March), and those collected on 25 and 26 May were hatched during 16 April-10 May (peak, 8 May). The durations from hatching dates to the time when the larvae were collected in the estuary in October, March, April, and May were 21, 44, 23, and 25 days, respectively. Except those collected in March, the durations were similar among months.

\section{TEMPORAL CHANGES IN MEAN AGE AND LENGTH AT ESTUARINE ARRIVAL AND GROWTH RATE}

Mean standard length, age and growth rates of E. punctifer at estuarine arrival were significantly different among sampling dates (one-way ANOVA, length: $F=13 \cdot 53$, age: $F=93 \cdot 70$, and growth rate: $F=170 \cdot 79$; all $P<0 \cdot 001$ ) [Fig. 4(a)]. Mean length was $c .25 .0 \mathrm{~mm}$ in October, decreased to $c .21 .0 \mathrm{~mm}$ in November, and then increased to $25 \mathrm{~mm}$ in February. Mean age was $c$. 25 days posthatching in October and November, but increased to 65 days in February. The temporal 

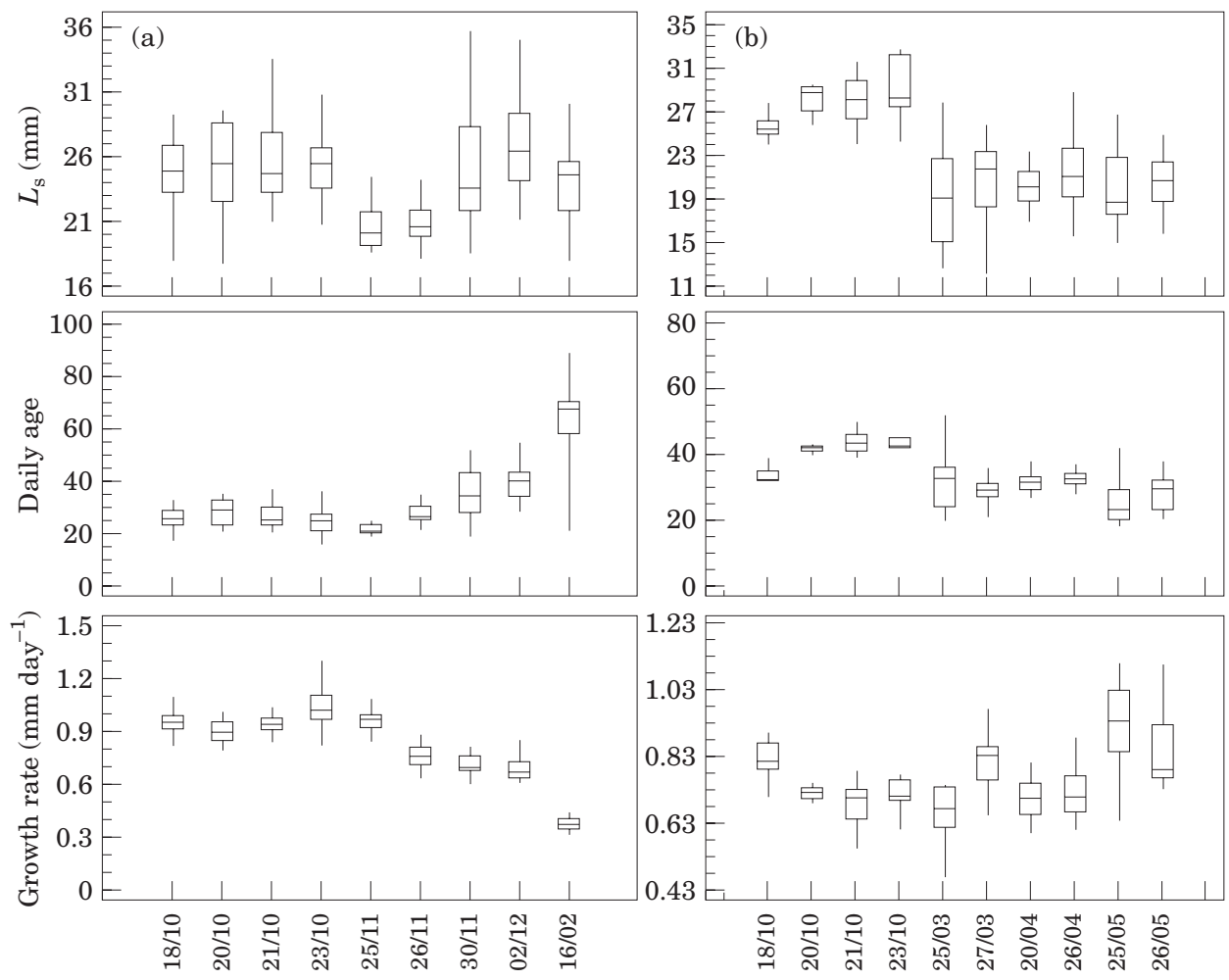

Date (day/month)

FIG. 4. Temporal changes in standard length, age and growth rate of Encrasicholina punctifer (a) and Engraulis japonicus (b) larvae at estuarine arrival in October and November 1992 and during February through May 1993. Box and whisker plot was used to illustrate the range, median, and skewness of the data.

change in mean growth rate was opposite to that of age, decreasing from $1.0 \mathrm{~mm}$ day $^{-1}$ in October to $0.4 \mathrm{~mm}$ day $^{-1}$ in February.

Mean standard length, age and growth rates of E. japonicus at estuarine arrival were also significantly different among catching dates (ANOVA, length: $F=17 \cdot 11$, age: $F=16 \cdot 39$, and growth rate: $F=16 \cdot 63$; all $P<0 \cdot 001$ ) [Fig. 4(b)]. Median standard length was c. $28 \mathrm{~mm}$ in October and $20 \mathrm{~mm}$ during March through May. Median age was c. 40 days in October, 33 days in March and April, and decreased to 27 days in May. The tendency in median growth rate was also opposite to that of age, $0.8 \mathrm{~mm}^{-1 a y}{ }^{-1}$ in October and increased from $0.7 \mathrm{~mm} \mathrm{day}^{-1}$ in March to $0.9 \mathrm{~mm} \mathrm{day}^{-1}$ in May.

Accordingly, growth rates of E. punctifer larvae were slower in winter than autumn. The growth rates of $E$. japonicus larvae were faster in the spring than in autumn.

\section{DIFFERENCE IN GROWTH RATE AMONG COHORTS}

The repeated-measures ANOVA indicated that otolith increment widths of E. punctifer larvae (Fig. 5) were highly significantly different among months $(P<0 \cdot 001)$ with a marginally significant interaction between month and over time 

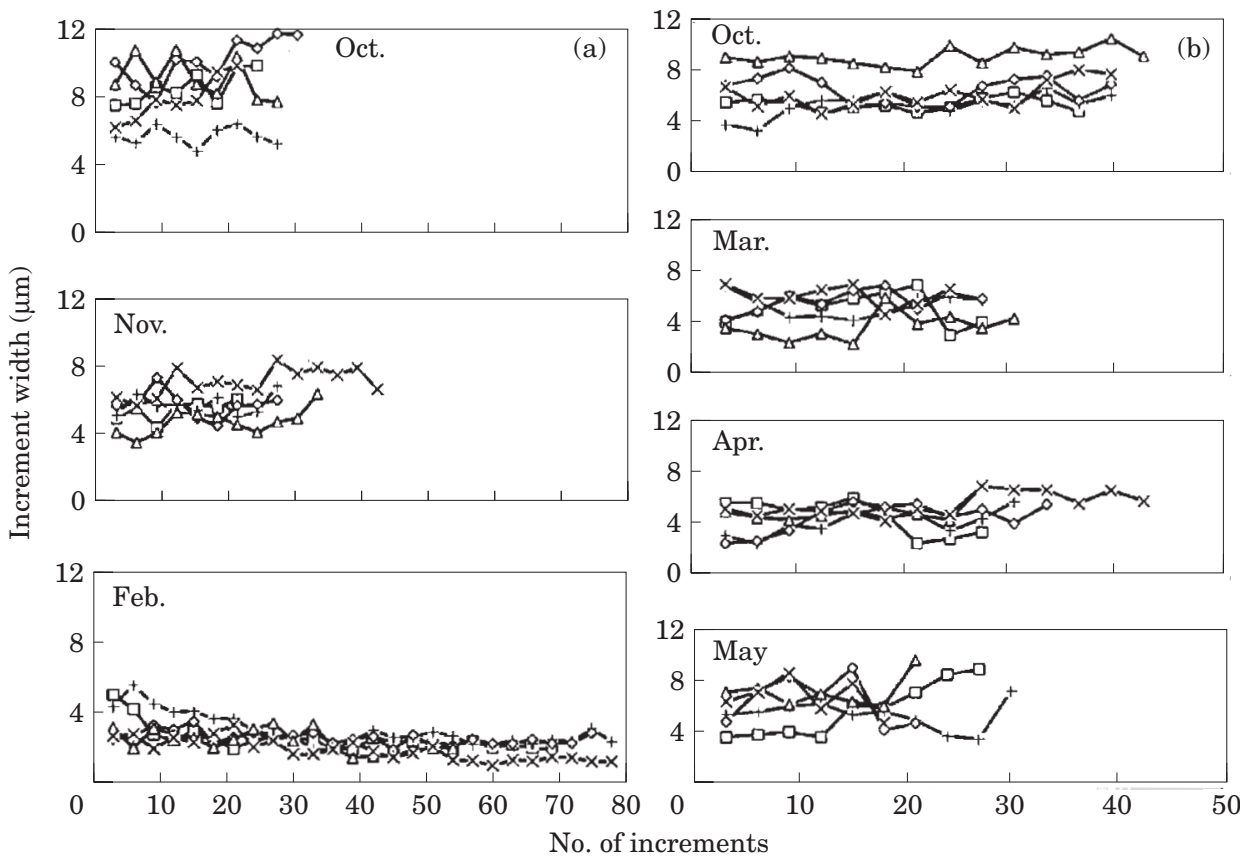

FIG. 5. Changes in 3-day mean increment widths of the otoliths of Encrasicholina punctifer (a) and Engraulis japonicus (b) larvae collected in the coastal waters off Tanshui River Estuary in October and November 1992 and during February through May 1993.

TABLE II. Repeated-measures ANOVA table for the 3-day mean increment widths with time for between-subjects effects and within-subjects effects

\begin{tabular}{|c|c|c|c|c|c|}
\hline Species & Source & d.f. & SS & $F$ value & $P$ \\
\hline \multirow[t]{7}{*}{ E. punctifer } & Between-subjects effects & & & & \\
\hline & Month & 2 & $619 \cdot 439$ & $28 \cdot 291$ & $<0 \cdot 001$ \\
\hline & Error & 12 & $131 \cdot 373$ & & \\
\hline & Within-subjects effects & & & & \\
\hline & Time & 8 & $5 \cdot 664$ & $1 \cdot 048$ & $0 \cdot 406$ \\
\hline & Time-month & 16 & $19 \cdot 432$ & $1 \cdot 798$ & $0 \cdot 042$ \\
\hline & Error (time) & 96 & $64 \cdot 830$ & & \\
\hline \multirow[t]{7}{*}{ E. japonicus } & Between-subjects effects & & & & \\
\hline & Month & 3 & $72 \cdot 447$ & $2 \cdot 777$ & 0.075 \\
\hline & Error & 16 & $139 \cdot 151$ & & \\
\hline & Within-subjects effects & & & & \\
\hline & Time & 8 & $7 \cdot 348$ & $0 \cdot 666$ & $0 \cdot 721$ \\
\hline & Time-month & 24 & $24 \cdot 185$ & $0 \cdot 731$ & $0 \cdot 812$ \\
\hline & Error (time) & 128 & $176 \cdot 519$ & & \\
\hline
\end{tabular}

$(0 \cdot 01<P<0 \cdot 05)$, but not significantly different over time (Table II). Mean widths decreased from $8.3 \mu \mathrm{m}_{\text {day }}{ }^{-1}$ in October to $6 \cdot 0 \mu \mathrm{m}_{\text {day }}{ }^{-1}$ in November and $2.6 \mu \mathrm{m} \mathrm{day}^{-1}$ in February. This indicated that the growth rate of E. punctifer was different among cohorts. 


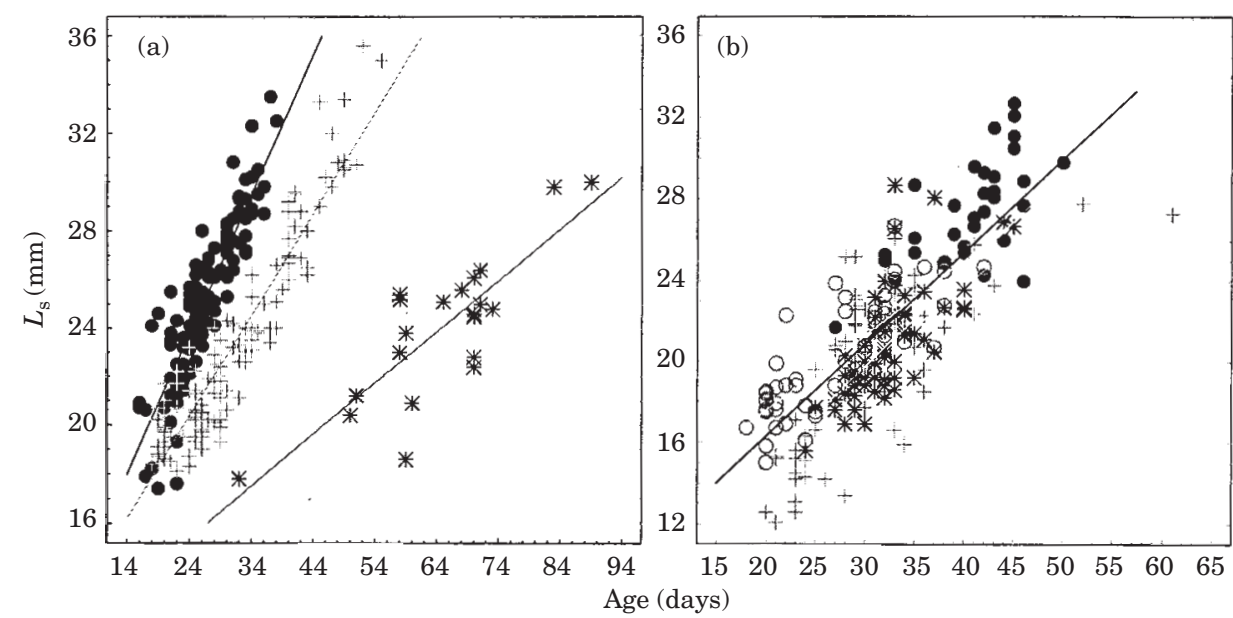

FIG. 6. Regressions of standard length on daily age of Encrasicholina punctifer (a) and Engraulis japonicus (b) larvae collected in the coastal waters off Tanshui River Estuary in October and November 1992 and during February through May 1993. (a) @, Oct.; +, Nov.; *, Feb. (b) @, Oct.; +, Mar.; *, Apr.; $\bigcirc$, May.

However, the differences in 3-day mean increment widths in otoliths of $E$. japonicus larvae were not significant among months and over time (Table II).

\section{REGRESSION OF LENGTH ON AGE AMONG COHORTS}

The regressions of standard length $\left(L_{\mathrm{S}}\right)$ on age $(A)$ of the E. punctifer larvae were calculated by months as follows:

$$
\begin{aligned}
& \text { October: } L_{\mathrm{S}}=9 \cdot 9+0 \cdot 6 \mathrm{~A}\left(n=120, r^{2}=0 \cdot 79\right) \\
& \text { November: } L_{\mathrm{S}}=10 \cdot 3+0 \cdot 4 \mathrm{~A}\left(n=120, r^{2}=0 \cdot 88\right) \\
& \text { February: } L_{\mathrm{S}}=10 \cdot 3+0 \cdot 2 \mathrm{~A}\left(n=21, r^{2}=0 \cdot 68\right)
\end{aligned}
$$

The regressions were significantly different among months (ANCOVA, $F=36 \cdot 17$, $P<0.01$ ) (Fig. 6). Slopes of the regressions decreased with increasing months, but intercepts were similar among months. These indicated that the sizes of larvae were similar at hatching, but growth rates were different among cohorts.

The regressions of standard length on age of E. japonicus larvae were not significantly different either in slopes or intercepts among months (ANCOVA, $F=0 \cdot 75$, NS) (Fig. 6). This indicated that growth rates of E. japonicus larvae were similar among cohorts. This was similar to the 3-day otolith mean increment width. Thus, the 4-month data were combined and the regression of standard length on age of the larvae was calculated as follows:

$$
L_{\mathrm{S}}=6 \cdot 4+0 \cdot 5 A\left(n=204, r^{2}=0 \cdot 63\right)
$$




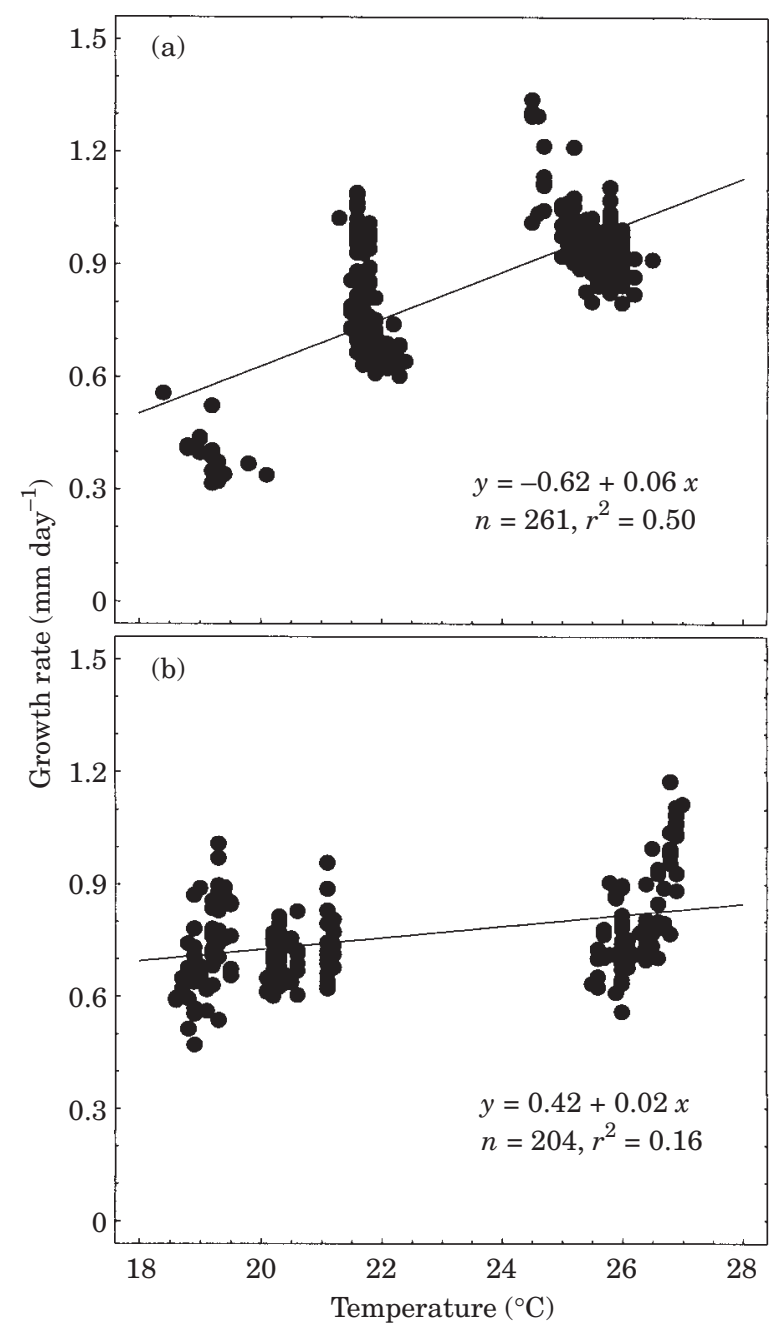

FIG. 7. Regression of the mean growth rate on mean temperature for Encrasicholina punctifer (a) and Engraulis japonicus (b) larvae collected in the coastal waters off Tanshui River Estuary in October and November 1992 and during February through May 1993.

RELATIONSHIPS BETWEEN GROWTH RATE AND WATER TEMPERATURE

The regression of growth rate $(y)$ of E. punctifer larvae on the mean water temperature $(x)$ from hatching to the time when the larvae were collected in the estuary was calculated as follows (Fig. 7):

$$
\begin{gathered}
y=-0 \cdot 62+0 \cdot 06 x \\
\left(n=261, r^{2}=0 \cdot 50, P<0 \cdot 01\right)
\end{gathered}
$$

This indicated that growth rates of the larvae correlated positively with water temperature. 
Similarly, the growth rate of E. japonicus larvae in relation to water temperature (Fig. 7) was also calculated:

$$
\begin{gathered}
y=0 \cdot 42+0 \cdot 02 x \\
\left(n=204, r^{2}=0 \cdot 16, P<0 \cdot 01\right)
\end{gathered}
$$

This indicated that the growth rates of E. japonicus were also correlated positively with temperature, but temperature explained only $16 \%$ of the variance.

\section{DISCUSSION}

The somatic and otolith growth of fish is influenced by temperature (Campana, 1984; Mosegaard et al., 1988; Campana \& Hurley, 1989), food levels (Neilson \& Geen, 1985; Rice et al., 1985; Al-Hossaini \& Pitcher, 1988; Tzeng \& $\mathrm{Yu}, 1992$ ), and the ontogenetic transitions of the fish (Brothers \& McFarland, 1981; Neilson et al., 1985; Hare \& Cowen, 1995). The change in somatic growth rate could be examined from the increment width of the otolith of fishes, because otolith growth is generally positively correlated to the somatic growth of fishes (Wilson \& Larkin, 1982; Volk et al., 1984; Campana \& Neilson, 1985). Mean increment widths were different among cohorts of the tropical clupeoid fish, Herklotsichthys castelnaui (Ogilby) (Thorrold \& Williams, 1989). We found that the wider increment widths in otoliths corresponded to the faster-growing cohorts of $E$. punctifer. The growth rate of E. japonicus was similar among cohorts. Accordingly, the difference in growth rate among cohorts was species specific.

Temperature is a principal factor promoting the growth rate of fishes (Crecco \& Savoy, 1985; Rutherford \& Houde, 1995). Growth rates of E. punctifer larvae were correlated positively with water temperature during the period from October to February. Temperature was $24-25^{\circ} \mathrm{C}$ in October, decreased to $21-23^{\circ} \mathrm{C}$ in November and to $<20^{\circ} \mathrm{C}$ during December through March in the coastal waters off Tanshui River Estuary (Wang et al., 1991; Tzeng \& Wang, 1992; Wang \& Tzeng, 1997a). The monthly changes of growth rates of $E$. punctifer were consistent with the seasonal changes in water temperature. Accordingly, the low growth rate of the fish in February may have been due to low water temperature.

Food supply is also an importrant biotic factor influencing the growth of fish larvae (Crecco \& Savoy, 1985; Tsai et al., 1991). The extent of influence depends on the production of prey organisms and the inter- and intraspecies competition of larval fishes. The correlation between growth rates of E. japonicus and water temperature was not highly significant, which may indicate that temperature was not the only factor to influence growth. In addition, growth rates of E. japonicus larvae varied both within and between individuals. This may indicate periods of food deficiency. The abundance of larval fishes in the coastal waters off Tanshui River Estuary was $c$. 10-fold higher in spring than in autumn and winter (Wang et al., 1991; Tzeng \& Wang, 1992). However, the zooplankton biomass was similar between spring and autumn (Chern \& Tzeng, 1994). These facts suggested that the food supply might be insufficient for the growth of 
E. japonicus larvae in spring. A sympatric species, Sardinella spp., co-occurred with E. japonicus in spring (Wang \& Tzeng, 1997a). Their diets were similar, and the ratio of empty stomachs in these two species was high (Chern \& Tzeng, unpubl. data). Insufficient food supply may play an important role in the growth of E. japonicus larvae.

The mean increment widths in otoliths of E. punctifer larvae were lowest in February, which corresponded to the period when water temperature and primary production were lowest in the coastal waters off Tanshui River Estuary (Wang et al., 1991; Tzeng \& Wang, 1992; Wang \& Tzeng, 1997a). The mean increment widths in otoliths of E. japonicus increased after February, which corresponded to the period of increasing primary production. This indicated that the seasonal changes in growth rate of the larvae among cohorts was coupled with the primary production.

A unique, overwintering cohort of E. punctifer larvae was found in February. This phenomenon was also found in E. japonicus in Sagami Bay of Japan (Tsuji, 1983). The overwintering $E$. punctifer larvae were hatched in late November and early December. Mean growth rates of the larvae were c. $0.4 \mathrm{~mm}$ day $^{-1}$ and decreased to $0 \cdot 2 \mathrm{~mm} \mathrm{day}^{-1}$ in the late stage. The low growth rate was similar to Tsuji's (1983) report for E. japonicus. The growth history of the overwintering cohort was similar between E. japonicus in Sagami Bay and E. punctifer in the coastal waters off Tanshui River Estuary. The spring-recruited population may mix with a portion of the autumn-spawned, slow-growing larvae.

In conclusion, differences in growth rates of the fish are recorded in the daily growth increments of otoliths. The growth rates of E. punctifer larvae were significantly different among cohorts but not in E. japonicus. The difference in growth rates of the former was influenced by water temperature, the latter possibly mainly by food supply.

This study was financially supported by the National Science Council of the Republic of China (NSC85-2311-B002-032). The authors are grateful to F. L. Chen and Y. C. Chen for their help in field work.

\section{References}

Al-Hossaini, M. \& Pitcher, T. J. (1988). The relation between daily rings, body growth and environmental factors in plaice, Pleuronectes platessa L., juvenile otoliths. Journal of Fish Biology 33, 409-418.

Al-Hossaini, M., Liu, Q. \& Pitcher, T. J. (1989). Otolith microstructure indicating growth and mortality among plaice, Pleuronectes platessa L., post-larval subcohorts. Journal of Fish Biology 35(Suppl. A), 81-90.

Brothers, E. B. \& McFarland, W. N. (1981). Correlations between otolith microstructure, growth, and life history transitions in newly recruited French grunts (Haemulon flavolineatum Desmarst, Haemulidae). Rapports et Procès-Verbaux des Réunions Conseil Internationale pour L’Exploration de la Mer 178, 369-374.

Campana, S. E. (1984). Interactive effects of age and environmental modifiers on the production of daily growth increments in otoliths of plainfin midshipman, Porichthys notatus. Fisheries Bulletin US 82, 165-177.

Campana, S. E. \& Hurley, P. C. F. (1989). An age- and temperature-mediated growth model for cod (Gadus morhua) and haddock (Melanogrammus aeglefinus) larvae in the Gulf of Maine. Canadian Journal of Fisheries and Aquatic Sciences 46, 603-613. 
Campana, S. E. \& Neilson, J. D. (1985). Microstructure of fish otoliths. Canadian Journal of Fisheries and Aquatic Sciences 42, 1014-1032.

Chern, Y.-T. \& Tzeng, W.-N. (1994). Feeding strategy of two larval anchovies, Encrasicholina punctifer and Stolephorus insularis, in the Tanshui River estuary, Taiwan-II. Prey selectivity and interspecific feeding competition. Journal of the Fisheries Society of Taiwan 21, 33-48.

Crecco, V. A. \& Savoy, T. F. (1985). Effects of biotic and abiotic factors on growth and relative survival of young American shad, Alosa sapidissima, in the Connecticut River. Canadian Journal of Fisheries and Aquatic Sciences 42, 1640-1648.

Crecco, V. A., Savoy, T. F. \& Gunn, L. (1983). Daily mortality rates of larval and juvenile American shad (Alosa sapidissima) in the Connecticut River with changes in year-class strength. Canadian Journal of Fisheries and Aquatic Sciences 40, $1719-1728$.

Cushing, D. H. (1975). Marine Ecology and Fisheries. London: Cambridge University Press.

Fortier, L. \& Leggett, W. C. (1985). A drift study of larval fish survival. Marine Ecology Progress Series 25, 245-257.

Hare, J. A. \& Cowen, R. K. (1995). Effect of age, growth rate, and ontogeny on the otolith size-fish size relationship in bluefish, Pomatomus saltatrix, and the implications for back-calculation of size in fish early life history stages. Canadian Journal of Fisheries and Aquatic Sciences 52, 1909-1922.

Hjort, J. (1914). Fluctuations in the great fisheries of northern Europe viewed in the light of biological research. Rapports et Procès-Verbaux des Réunions Conseil Internationale pour L'Exploration de la Mer 19, 1-228.

Houde, E. D. (1987). Fish early life dynamics and recruitment variability. American Fisheries Society Symposium 2, 17-29.

Jones, C. (1985). Within-season differences in growth of larval Atlantic herring, Clupea harengus harengus. Fisheries Bulletin US 83, 289-298.

Leak, J. C. \& Houde, E. D. (1987). Cohort growth and survival of bay anchovy Anchoa mitchilli larvae in Biscayne Bay, Florida. Marine Ecology Progress Series 37, 109-122.

Lough, R. G., Pennington, M., Bolz, G. R. \& Rosenberg, A. A. (1982). Age and growth of larval Atlantic herring, Clupea harengus L., in the Gulf of Maine-Georges Bank region based on otolith growth increments. Fisheries Bulletin US 80, 187-199.

Methot, R. D. (1983). Seasonal variation in survival of larval Engraulis mordax estimated from the age distributions of juveniles. Fisheries Bulletin US 81, $741-750$.

Methot, R. J., Jr \& Kramer, D. (1979). Growth of northern anchovy, Engraulis mordax, larvae in the sea. Fisheries Bulletin US 77, 413-423.

Moksness, E. \& Fossum, P. (1991). Distinguishing spring- and autumn-spawned herring larvae (Clupea harengus L.) by otolith microstructure. ICES Journal of Marine Science 48, 61-66.

Moksness, E. \& Fossum, P. (1992). Daily growth rate and hatching-date distribution of Norwegian spring-spawning herring (Clupea harengus L.). ICES Journal of Marine Science 49, 217-221.

Mosegaard, H., Svedäng, H. \& Taberman, K. (1988). Uncoupling of somatic and otolith growth rates in Arctic char (Salvelinus alpinus) as an effect of differences in temperature response. Canadian Journal of Fisheries and Aquatic Sciences 45, $1514-1524$.

Neilson, J. D. \& Geen, G. H. (1985). Effects of feeding regimes and diel temperature cycles on otolith increment formation in juvenile chinook salmon, Oncorhynchus tshawytscha. Fisheries Bulletin US 83, 91-101.

Neilson, J. D., Geen, G. H. \& Chan, B. (1985). Variability in dimensions of salmonid otolith nuclei: implications for stock identification and microstructure interpretation. Fisheries Bulletin US 83, 81-89.

Pannella, G. (1971). Fish otoliths: daily growth layers and periodical patterns. Science 173, 1124-1127. 
Rice, J. A., Crowder, L. B. \& Holey, M. E. (1985). Evaluating otolith analysis for bloater Coregonus hoyi: do otoliths ring true? Transactions of the American Fisheries Society 114, 532-539.

Rutherford, E. S. \& Houde, E. D. (1995). The influence of temperature on cohortspecific growth, survival, and recruitment of striped bass, Morone saxatilis, larvae in Chesapeake Bay. Fisheries Bulletin US 93, 315-332.

Secor, D. H. \& Dean, J. M. (1989). Somatic growth effects on the otolith-fish size relationships in young pond-reared striped bass, Morone saxatilis. Canadian Journal of Fisheries and Aquatic Sciences 46, 113-121.

Secor, D. H., Dean, J. M. \& Laban, E. H. (1992). Otolith removal and preparation for microstructure examination. Canadian Special Publication in Fisheries and Aquatic Sciences 117, 19-57.

Smith, P. E. (1985). Year-class strength and survival of 0-group clupeoids. Canadian Journal of Fisheries and Aquatic Sciences 42(Suppl. 1), 69-82.

Steel, R. G. D. \& Torrie, J. H. (1980). Principles and Procedures of Statistics. Auckland: McGraw-Hill.

Struhsaker, P. \& Uchiyama, J. H. (1976). Age and growth of the nehu, Stolephorus purpureus (Pisces: Engraulidae), from the Hawaiian Islands as indicated by daily growth increments of sagittae. Fisheries Bulletin US 74, 9-17.

Thorrold, S. R. (1989). Estimating some early life history parameters in a tropical clupeid, Herklotsichthys castelnaui, from daily growth increments in otoliths. Fisheries Bulletin US 87, 73-83.

Thorrold, S. R. \& Williams, D. McB. (1989). Analysis of otolith microstructure to determine growth histories in larval cohorts of a tropical herring (Herklotsichthys castelnaui). Canadian Journal of Fisheries and Aquatic Sciences 46, 1615-1624.

Townsend, D. W. \& Graham, J. J. (1981). Growth and age structure of larval Atlantic herring, Clupea harengus harengus, in the Sheepscot River Estuary, Maine, as determined by daily growth increments in otoliths. Fisheries Bulletin US 79, 123-130.

Tsai, C.-F., Wiley, M. \& Chai, A.-L. (1991). Rise and fall of the Potomac River striped bass stock: a hypothesis of the role of sewage. Transactions of the American Fisheries Society 120, 1-22.

Tsuji, S. (1983). Study of recruitment mechanism of larval Japanese anchovy, Engraulis japonicus, in the fishing ground of Sagami Bay by daily growth increments. Ph.D. dissertation, Tokyo University.

Tsuji, S. \& Aoyama, T. (1984). Daily growth increments in otoliths of Japanese anchovy larvae Engraulis japonicus. Bulletin of Japanese Society of Scientific Fisheries 50, 1105-1108.

Tzeng, W.-N. \& Yu, S.-Y. (1992). Effects of starvation on the formation of daily growth increments in the otoliths of milkfish, Chanos chanos (Forsskal), larvae. Journal of Fish Biology 40, 39-48.

Tzeng, W.-N. \& Wang, Y.-T. (1992). Structure, composition and seasonal dynamics of the larval and juvenile fish community in the mangrove estuary of Tanshui River, Taiwan. Marine Biology 113, 481-490.

Volk, E. C., Wissmar, R. C., Simenstad, C. A. \& Eggers, D. M. (1984). Relationship between otolith microstructure and the growth of juvenile chum salmon (Oncorhynchus keta) under different prey rations. Canadian Journal of Fisheries and Aquatic Sciences 41, 126-133.

Wang, Y.-T. \& Tzeng, W.-N. (1997a). Temporal succession and spatial segregation of clupeoid larvae in the coastal waters of the Tanshui River Estuary, northern Taiwan. Marine Biology 129, 23-32.

Wang, Y.-T. \& Tzeng, W.-N. (1997b). A quick method to identify engraulid fish larvae in the Tanshui River Estuary of northern Taiwan. Acta Zoologica Taiwanica 8, $103-119$.

Wang, Y.-T., Tzeng, W.-N. \& Lee, S.-C. (1991). A preliminary study on species composition and seasonal abundance of fish eggs and larvae from the coastal 
waters adjacent to the Tanshui River estuary, Taiwan (1984-1985). Journal of the Fisheries Society of Taiwan 18, 7-20.

Wilson, K. H. \& Larkin, P. A. (1982). Relationship between thickness of daily growth increments in sagittae and change in body weight of sockeye salmon (Oncorhynchus nerka) fry. Canadian Journal of Fisheries and Aquatic Sciences 39, $1335-1339$.

Winer, B. (1971). Statistical Principles in Experimental Design, 2nd edn. New York: McGraw-Hill. 